\title{
Pengaruh service quality terhadap kepuasan pendengar media lembaga penyiaran publik radio $\mathrm{XYZ}$
}

\section{Ermalina}

Program Studi Manajemen, STIE Ahmad Dahlan

\begin{abstract}
This study describes the effect of service quality on customer satisfaction at the XYZ Radio, a Public Broadcasting Institute. A total of 50 respondents were taken as samples by purposive sampling method. The data analysis method used is simple linear regression, correlation test and hypothesis test (t-test.). The results of the associative quantitative research above are service quality has a positive and a strong significant influence and correlation to customer satisfaction.
\end{abstract}

\section{Abstrak}

Studi ini menjelaskan pengaruh kualitas layanan terhadap kepuasan pelanggan di Radio XYZ, sebuah Lembaga Penyiaran Publik. Sebanyak 50 orang diambil sebagai sampel dengan metode purposive sampling. Metode analisis data yang digunakan adalah regresi linier sederhana, uji korelasi dan uji hipotesis (uji-t) hasil penelitian kuantitatif asosiatif di atas yaitu kualitas layanan memiliki pengaruh positif dan kuat serta korelasi dan kepuasan terhadap kepuasan pelanggan.

*Email korespondensi: ermalina1962@gmail.com

Pedoman Sitasi: Ermalina (2019). Pengaruh service quality terhadap kepuasan pendengar media lembaga penyiaran publik radio XYZ. Jurnal Manajemen Strategi dan Aplikasi Bisnis, 2(1), 31-38
Paper type

Research paper

Keywords: Service quality, Consumer Satisfaction

Received: 15 Dec 2018

Accepted: 23 Jan 2018

Online: 06 Feb 2019

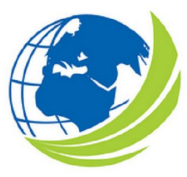

\author{
Jurnal Manajemen \\ Strategi dan Aplikasi \\ Bisnis, Vol 2, No.1, April \\ 2019, \\ pp. 31 - 38 \\ eISSN 2655-237X
}




\section{PENDAHULUAN}

Kepuasan pelanggan telah menjadi tema sentral pengambilan keputusan manajerial di seluruh dunia dan telah dijadikan tujuan operasional prioritas tinggi. Kepuasan pelanggan tergantung pada kinerja produk (layanan) yang dirasakan dibandingkan harapan pembeli. Jika kinerja melebihi atau sesuai dengan harapan, pelanggan sangat puas atau senang. (Kotler dan Keller (2006). Konsep ini berlaku untuk seluruh jenis layanan maupun produk yang dihasilkan oleh perusahaan, termasuk di sektor komunikasi.

Salah satu tantangan utama yang dihadapi perusahaan telekomunikasi adalah bagaimana mereka mengelola kualitas layanan mereka, yang sangat mempengaruhi kepuasan pelanggan. Kualitas layanan dan kepuasan pelanggan sangat penting dalam menjaga loyalitas pelanggan. Industri telekomunikasi telah banyak berinvestasi pada kepuasan pelanggan dengan merancang sistem pengukuran skala besar dan memulai proyek peningkatan kepuasan pelanggan, berdsarkan studi literatur mengenai kepuasan pelanggan memperlihatkan bahwa faktor penentu paling langsung kepuasan adalah kualitas layanan, harapan pelanggan dan nilai yang dirasakan dan kinerja (Parasuraman, et al., 1988). Sebagian besar akademisi dan peneliti menerima bahwa kualitas layanan pada dasarnya berkaitan dengan apa yang pelanggan anggap produk / kinerja layanan. Menurut Ahemed et al. (2010) kualitas layanan adalah penentu utama kepuasan pelanggan di kedua bisnis, manufaktur maupun layanan. Gronroos (2001) menyatakan bahwa kualitas layanan yang dirasakan merupakan penentu penting dari kepuasan pelanggan yang memiliki dimensi kognitif dan afektif ebih dari sekadar penilaian kognitif pelanggan tentang penawaran penyedia layanan.

Larsen (2016) menyebutkan ketika menghadapi tekanan ekonomi dan teknologi baru, nilainilai demokrasi yang melekat pada penyiaran layanan publik telah lebih dieksplor dan dilegitimasi. Pembelaan terhadap nilai-nilai utama jurnalisme yang independen telah mengambil bentuk yang berbeda, tergantung pada sifat perubahan sosial dan logika budaya dari konteks sosial. Menurut Potluri dan Mangnale (2010) bidang ketidakpuasan utama pada layanan komunikasi adalah kualitas layanan, struktur tarif, perjumpaan layanan, proses pengiriman layanan, area pembayaran tagihan, prosedur penanganan pengaduan dan layanan purna jual.

Sektor penyiaran menghadapi perubahan besar, khususnya dalam persaingan yang berkembang antara sektor publik dan swasta, terutama dalam hal penyediaan konten berkualitas tinggi. Penelitian mengenai kualitas penyiaran radio masih relatif kurang mendapatkan perhatian peneliti. Kualitas layanan penyiaran dalam beberapa tahun terakhir lebih difokuskan pada aspek teknis dan mengabaikan aspek pemasaran konsumen sehingga menarik untuk diteliti. Berdasarkan keterbatasan tersebut, penelitian ini bertujuan untuk: (1) untuk mengetahui pengaruh kualitas pelayanan terhadap kepuasan konsumen pada Media Lembaga Penyiaran Publik Radio XYZ; (2) mengetahui dan menganalisis hubungan service quality denganan kepuasan konsumen pada Media Lembaga Penyiaran Publik Radio XYZ

\section{KAJIAN PUSTAKA}

Kualitas pelayanan

Konsep service quality pada dasarnya memberikan persepsi secara konkrit mengenai kualitas suatu layanan. Konsep service quality ini merupakan suatu revolusi secara menyeluruh, permanen dalam mengubah cara pandang manusia dalam menjalankan atau mengupayakan usaha-usahanya yang berkaitan dengan proses dinamis, berlangsung, terus menerus di dalam memenuhi harapan, keinginan dan kebutuhan. Hal ini sesuai dengan teori "Quality" yang dikemukakan oleh Marcel (2003:192) bahwa keberhasilan suatu tindakan jasa ditentukan oleh kualitas. Kualitas merupakan apresiasi tertinggi dari tindakan pelayanan.

Stemvelt (2004:210) menyatakan bahwa konsep service quality adalah suatu persepsi tentang revolusi kualitas secara menyeluruh yang terpikirkan dan menjadi suatu gagasan yang harus 
dirumuskan (formulasi)agarpenerapannya (implementasi) dapatdiujikembali (evaluasi),untuk menjadi suatu proses yang dinamis, berlangsung, terus menerus dalam memenuhi kepuasan pelanggan. Teori "tujuan" yang dikembangkan oleh Samuelson (2000:84) bahwa tujuan adalah asumsi kepuasan yang disesuaikan dengan tingkat service quality.

Unsur-unsur service quality

Lima dimensi kualitas pelayanan yang dikembangkan oleh Parasuraman atau dikenal dengan istilah SERVUAL antara lain terdiri dari faktor fisik (tangibles), keandalan (reliability), responsivitas (responsiveness), jaminan (assurance), dan empati (emphaty). Tangibles merujuk pada fasilitas fisik, alat atau peralatan yang digunakan untuk menyediakan layanan dan penampilan staf. Fasilitas fisik seperti rambu, kenyamanan, aksesibilitas, fungsionalitas, dan kebersihan (D'Cunha dan Suresh, 2015). Faktor ini adalah dimensi kualitas layanan yang kritis untuk meningkatkan kinerja kualitas dalam industri jasa (Radet al., 2010, dalam Ahmed et al., 2017).

Keandalan melibatkan konsistensi layanan dan ketergantungan, yang mengacu pada kemampuan untuk memberikan layanan secara andal dan akurat yang diinginkan pelanggan (Parasuramanet al., 1985 dalam Ahmed et al., 2017). Jika penyedia layanan menepati janji mereka, maka kepuasan pelanggan meningkat dan kepercayaan mereka pada penyedia layanan meningkat karena kinerja penyedia secara bertahap meningkat dan secara konsisten memenuhi harapan pelanggan (Radet al., 2010 dalam Ahmed et al., 2017).

Responsiveness menyangkut kesediaan atau kesediaan penyedia layanan untuk menawarkan layanan secara cepat ( Parasuramanet al., 1985). Dimensi ini berkaitan dengan ketepatan waktu, seperti memberikan layanan cepat kepada pelanggan, mengatur janji sesegera mungkin, segera mengirimkan slip transaksi kepada pelanggan sehingga ia tidak membentuk kesan yang salah dan menelepon pelanggan dengan cepat (Calisiret al., 2014). Jika penyedia layanan meningkatkan respons mereka terhadap pelanggan, maka kemungkinan akan memiliki efek positif pada kepuasan pelanggan (Parasuramanet al., 1985; Radet al., 2010 dalam Ahmed et al., 2017).

Jaminan mengacu pada pengetahuan, kesopanan, dan kemampuan karyawan untuk menyampaikan kepercayaan dan kepercayaan diri . Karyawan harus memiliki pengetahuan dan keterampilan yang diperlukan untuk memberikan layanan terbaik kepada pelanggan mereka. Sopan santun berarti kesopanan, rasa hormat, pertimbangan dan keramahan, seperti pertimbangan untuk properti pelanggan / konsumen. Menyampaikan kepercayaan dan kepercayaan berarti kepercayaan, kepercayaan dan kejujuran. Ini melibatkan memiliki kepentingan terbaik pelanggan di hati seperti karakteristik personil kontak (Kitapciet al., 2014 dalam Ahmed et al., 2017).

Empati mengacu pada kepedulian, mengetahui tuntutan pelanggan dan perhatian individual yang diberikan kepada pelanggan. Kapasitas untuk memahami kebutuhan pelanggan mengacu pada kemampuan untuk merespons mereka seperti mengenali pelanggan reguler dan mempelajari persyaratan khusus mereka (Parasuramanet al., 1985). Empati penyedia dan hubungan pelanggan memiliki pengaruh positif pada kepuasan pelanggan (Fitzpatrick, 1991; Zareiet al., 2012, dalam Ahmed et al., 2017)

Kepuasan konsumen

Seperti yang dikemukakan oleh Kotler (2005:46), tentang kepuasan sebagai berikut : "Kepuasan adalah tingkat perasaan seseorang setelah membandingkan kinerja (hasil) yang dirasakan dibandingkan dengan harapannya". Kepuasan tidak dapat diukur sebab banyak pelanggan yang hanya merasa puas mudah untuk berubah fikiran bila mendapatkan tawaran yang lebih baik dan kepuasan atau ketidakpuasan merupakan evaluasi dari emosi setiap individu. Ada yang mudah puas dan ada yang sukar untuk diberi kepuasan tetapi tetap merasa senang pada saat itu. 
Jadi pengertian kepuasan pelanggan berarti bahwa kinerja suatu barang sekurangkurangnya sama dengan apa yang diharapkan karena kepuasan dan ketidakpuasan pelanggan merupakan penilaian antara harapan pada pembelian dengan kinerja yang dirasakan pada purna pembelian dari produk atau jasa yang bersangkutan. Dengan demikian walaupun sulit untuk mengukur kepuasan/ketidakpuasan setidaknya perusahaan memiliki strategi yang menyangkut pada kepuasan melalui penyusunan strategi perusahaan untuk meningkatkan dan mempertahankan keunggulan daya saing yang berkelanjutan bagi masa mendatang.

Harapan pelanggan akan dapat dibentuk oleh pengalaman masa lalu, komentar dari kerabatnya serta janji dan informasi pemasar dan saingannya. Pelanggan yang puas akan setia lebih lama, kurang sensitif terhadap harga dan memberi komentar yang baik tentang perusahaan. Untuk menciptakan kepuasan pelanggan, perusahaan harus menciptakan dan mengelola suatu sistem untuk memperoleh pelanggan yang lebih banyak dan kemampuan untuk mempertahankan pelanggannya.

Literatur kepuasan pelanggan menegaskan bahwa faktor penentu paling langsung kepuasan adalah kualitas layanan, harapan pelanggan dan nilai yang dirasakan dan kinerja (Parasuraman, et al., 1988). Sebagian besar peneliti menerima bahwa kualitas layanan pada dasarnya berkaitan dengan apa yang pelanggan mengenai kinerja produk / layanan. Gronroos (2001) menyatakan bahwa kualitas layanan yang dirasakan merupakan penentu penting dari kepuasan pelanggan yang memiliki kognitif dan afektif dimensi lebih dari sekadar penilaian kognitif pelanggan tentang penawaran penyedia layanan.

\section{METODE PENELITIAN}

\section{Data}

Penelitian ini dilaksanakan di Kota Jakarta tepatnya pada Media Lembaga Penyiaran Publik Radio XYZ dengan waktu penelitian berlangsung selama 3 (tiga) bulan, mulai bulan November 2017 sampai Januari 2018. Metode pengumpulan data dalam penelitian ini dimaksudkan untuk memperoleh data yang relevan dan akurat dengan masalah yang dibahas. Metode pengumpulan data tersebut adalah sebagai berikut:

Observasi adalah metode dipergunakan sebagai salah satu piranti dalam pengumpulan data berdasarkan pengamatan secara langsung pengaruh service quality terhadap kepuasan konsumen pada Media Lembaga Penyiaran Publik Radio XYZ

a. Wawancara yaitu dialog secara langsung untuk memperoleh informasi dari responden terpilih dalam menghimpun informasi yang relevan dengan penelitian yang akan diadakan di Media Lembaga Penyiaran Publik Radio XYZ

b. Kuesioner adalah teknik pengumpulan data dengan mengajukan sejumlah pertanyaan secara tertulis yang diberikan kepada responden dengan maksud untuk memperoleh data yang akurat dan valid.

c. Dokumentasi yaitu data yang diperoleh melalui pencatatan-pencatatan dari dokumendokumen yang terdapat pada lokasi penelitian.

Populasi dan Sampel

Populasi adalah kelompok elemen yang lengkap, umumnya berupa orang,obyek, transaksi atau kejadian, di mana peneliti mempelajari atau menjadikannya obyek penelitian. Populasi merupakan jumlah keseluruhan dari objek penelitian yaitu 50 Agency. Sampel adalah suatu himpunan atau bagian dari unit populasi. Pemilihan sampel dilakukan dengan menggunakan purposive sampling yaitu penunjukan langsung responden sesuai kebutuhan penelitian. Jadi besar sampel dalam penelitian ini ditetapkan 50 responden. 
Pengukuran Variabel

Kualitas pelayanan diukur berdasrkan lima dimensi kualitas pelayanan yang dikembangkan oleh Parasuraman atau dikenal dengan istilah SERVUAL antara lain terdiri dari faktor fisik (tangibles), keandalan (reliability), responsivitas (responsiveness), jaminan (assurance), dan empati (emphaty). Teknik kuesioner digunakan untuk mengumpulkan data dan mengembangkan model SERVQUAL berbasis kuesioner yang mencakup lima dimensi kepuasan pelanggan. Menurut Malhotra dan Birks (2003, hal. 224), pendekatan survei ini adalah metode pengumpulan data primer yang paling umum dalam riset pemasaran dan kelebihannya adalah administrasi sederhana dan konsistensi data.

Teknik analisis

The Statistical Package for Social Sciences (SPSS 20) digunakan untuk menganalisis data yang dikumpulkan. Statistik deskriptif (statistik frekuensi) diterapkan untuk menilai tingkat kepuasan pelanggan. Model regresi linier sederhana dan t-statistik digunakan untuk menentukan kepentingan relatif setiap variabel independen dalam mempengaruhi kepuasan pelanggan. Model regresi linier digunakan untuk menguji hubungan kasual antara kualitas pelayanan dengan kepuasan pelanggan.

\section{HASIL DAN PEMBAHASAN}

Uji validitas dan reliabilitas

Uji validitas dalam penelitian ini menggunakan pendekatan validitas konstrak menggunakan analisis faktor. Prinsip yang digunakan analisis factor adalah mengelompokkan data berdasarkan interkorelasi antar butir. Nilai interkorelasi antar variabel dapat dilihat dari anti-image, dimana jika tidak ada korelasi yang lebih dari 0.30 maka dapat dianggap analisis factor tidak dapat dilakukan. Parameter pertama adalah dengan memperhatikan nilai measure of sampling adequacy (MSA). Menurut Hair, dkk (2006), nilai MSA berkisar antara 0 - 1 ketika setiap variabel diprediksi secara sempurna tanpa error dari variabel lain. Nilai 0.80 atau lebih dianggap pantas, 0.70 atau lebih dianggap lumayan, 0.60 atau lebih dianggap sedang, 0.50 atau lebih dianggap menyedihkan/ buruk, dan di bawah 0.50 tidak dapat diterima (Suryani dan Hendryadi, 2015). Hasil analisis memperlihatkan bahwa dua variabel, baik kualitas pelayanan dan kepuasan pelanggan telah memenuhi syarat analisis faktor dengan nilai koefisien bobot faktor seluruh item lebih dari 0.50 sehingga dinyatakan valid.

Studi uji reliabilitas menggunakan Cronbach alpha untuk menilai konsistensi internal instrumen penelitian. Cronbach's $\alpha$ (alpha) adalah koefisien reliabilitas. Ini biasanya digunakan sebagai ukuran konsistensi internal atau reliabilitas skor tes psikometri untuk sampel responden. Reliabilitas dalam penelitian ini yang dinilai dengan koefisien alpha, ditemukan 0,852 sebagai indikasi penerimaan skala untuk analisis lebih lanjut.

\section{Analisis korelasi}

Analisis korelasi membantu untuk mendapatkan wawasan tentang arah dan kekuatan korelasi antar variabel. Koefisien korelasi mengambil nilai antara -1 dan 1 mulai dari yang berkorelasi negatif (-1) hingga tidak berkorelasi (0) hingga berkorelasi positif (+). Tanda koefisien korelasi menentukan arah hubungan. Nilai absolut menunjukkan kekuatan korelasi. Analisis korelasi dilakukan sebelum melakukan analisis regresi. Hasil perhitungan SPSS korelasi $r=0,821$, artinya antara hubungan Service quality (X) terhadap Kepuasan Konsumen (Y) mempunyai hubungan positif dan kuat.

Analisis regresi

Hasil Analisa determinasi dari perhitungan SPSS KD $=67,4 \%$, artinya : bahwa pengaruh service quality (X) terhadap Kepuasan Konsumen (Y) mempunyai kontribusi sebesar 67,4 \%, sedangkan sisanya yaitu 32,6\% merupakan pengaruh dari faktor lain.

Hasil dari Program SPSS diperoleh persamaan regresi $\mathrm{Y}=3,171+0,764 \mathrm{X}$. Hasil analisa persamaan regresi $\mathrm{Y}=3,171+0,764 \mathrm{X}$, artinya pengaruh Service quality $(\mathrm{X})$ terhadap Kepuasan 
Konsumen ( $\mathrm{Y}$ ) adalah positif dan apabila setiap kenaikan Service quality (X) bertambah sebesar satu (1) konstanta maka akan mempengaruhi Kepuasan Konsumen akan bertambah atau meningkat sebesar 0,764 .

Tabel 1. Hasil regresi

\begin{tabular}{|c|c|c|c|c|c|c|}
\hline & & Unstandardizec & Coefficients & $\begin{array}{c}\text { Standardized } \\
\text { Coefficients }\end{array}$ & & \\
\hline & del & B & Std. Error & Beta & $\mathrm{t}$ & Sig. \\
\hline 1 & (Constant) & 3.171 & 1.477 & & 3.231 & .002 \\
\hline & Service quality & .764 & .054 & .912 & 15.380 & .000 \\
\hline
\end{tabular}

Hasil regresi menunjukkan bahwa ada hubungan yang signifikan antara berbagai atribut layanan dan kepuasan pelanggan. Jaringan, layanan perawatan pelanggan secara keseluruhan, faktor fisik (tangibles), keandalan (reliability), responsivitas (responsiveness), jaminan (assurance), dan empati (emphaty) signifikan terkait dengan kepuasan pada tingkat signifikansi 0,001.

Nilai Beta menunjukkan besarnya hubungan antara variabel, nilai yang lebih tinggi menjadi indikasi hubungan yang kuat. Dalam penelitian ini, kemampuan untuk memberikan solusi untuk masalah pelanggan telah mendapat koefisien Beta 0.761. Implikasi dari hasil ini adalah bahwa kualitas pelayanan dapat memberikan efek positif pada kepuasan pelanggan, dengan demikian upaya untuk meningkatkan kepuasan dapat dilakukan, terutama pada faktor fisik.

Bukti fisik dalam service quality adalah bentuk aktualisasi nyata secara fisik dapat terlihat atau digunakan oleh pegawai sesuai dengan penggunaan dan pemanfaatannya yang dapat dirasakan membantu pelayanan yang diterima oleh orang yang menginginkan pelayanan, sehingga puas atas pelayanan yang dirasakan, yang sekaligus menunjukkan prestasi kerja atas pemberian pelayanan yang diberikan (Parasuraman, 2001:32). Berarti dalam memberikan pelayanan, setiap orang yang menginginkan pelayanan dapat merasakan pentingnya bukti fisik yang ditunjukkan oleh pengembang pelayanan, sehingga pelayanan yang diberikan memberikan kepuasan.Bentuk pelayanan bukti fisik biasanya berupa sarana dan prasarana pelayanan yang tersedia, teknologi pelayanan yang digunakan, performance pemberi pelayanan yang sesuai dengan karakteristik pelayanan yang diberikan dalam menunjukkan prestasi kerja yang dapat diberikan dalam bentuk pelayanan fisik yang dapat dilihat.

Bentuk-bentuk pelayanan fisik yang ditunjukkan sebagai service quality dalam rangka meningkatkan prestasi kerja, merupakan salah satu pertimbangan dalam manajemen organisasi. Tidak dapat dipungkiri bahwa dalam suatu organisasi modern dan maju, pertimbangan dari para pengembang pelayanan, senantiasa mengutamakan bentuk kualitas kondisi fisik yang dapat memberikan apresiasi terhadap orang yang memberi pelayanan. Martul (2004:49) menyatakan bahwa service quality berupa kondisi fisik merupakan bentuk service quality nyata yang memberikan adanya apresiasi dan membentuk imej positif bagi setiap individu yang dilayaninya dan menjadi suatu penilaian dalam menentukan kemampuan dari pengembang pelayanan tersebut memanfaatkan segala kemampuannya untuk dilihat secara fisik, baik dalam menggunakan alat dan perlengkapan pelayanan, kemampuan menginovasi dan mengadopsi teknologi, dan menunjukkan suatu performance tampilan yang cakap, berwibawa dan memiliki integritas yang tinggi sebagai suatu wujud dari prestasi kerja yang ditunjukkan kepada orang yang mendapat pelayanan.

Faktor kedua adalah keandalan. Setiap pelayanan memerlukan bentuk pelayanan yang handal, artinya dalam memberikan pelayanan, setiap pegawai diharapkan memiliki kemampuan dalam pengetahuan, keahlian, kemandirian, penguasaan dan profesionalisme kerja yang tinggi, sehingga aktivitas kerja yang dikerjakan menghasilkan bentuk pelayanan yang memuaskan, tanpa ada keluhan dan kesan yang berlebihan atas pelayanan yang diterima oleh masyarakat (Parasuraman, 1991). 
Tuntutan kehandalan pegawai dalam memberikan pelayanan yang cepat, tepat, mudah dan lancar menjadi syarat penilaian bagi orang yang dilayani dalam memperlihatkan aktualisasi kerja pegawai dalam memahami lingkup dan uraian kerja yang menjadi perhatian dan fokus dari setiap pegawai dalam memberikan pelayanannya. Inti pelayanan kehandalan adalah setiap pegawai memiliki kemampuan yang handal, mengetahui mengenai seluk belum prosedur kerja, mekanisme kerja, memperbaiki berbagai kekurangan atau penyimpangan yang tidak sesuai dengan prosedur kerja dan mampu menunjukkan, mengarahkan dan memberikan arahan yang benar kepada setiap bentuk pelayanan yang belum dimengerti oleh masyarakat, sehingga memberi dampak positif atas pelayanan tersebut yaitu pegawai memahami, menguasai, handal, mandiri dan profesional atas uraian kerja yang ditekuninya.

\section{KESIMPULAN}

Tujuan utama dari penelitian ini adalah untuk menilai kepuasan konsumen pada layanan radio Media Lembaga Penyiaran Publik Radio XYZ, faktor-faktor yang mempengaruhi kepuasan menggunakan instrumen SERVQUAL. Kepuasan pelanggan adalah penilaian berdasarkan pengalaman yang dibuat oleh pelanggan seberapa jauh harapan mereka tentang fungsionalitas keseluruhan dari layanan yang diperoleh dari perusahaan. Sehubungan dengan pengukuran kepuasan pelanggan, hasil menunjukkan bahwa pelanggan cukup puas dengan kinerja Media Lembaga Penyiaran Publik Radio XYZ. Hasil penelitian menunjukkan adanya korelasi yang kuat antara kualitas pelayanan dengan kepuasan konsumen.

Implikasi dari temuan ini adalah untuk meningkatkan kepuasan pelanggan, Lembaga Penyiaran Publik Radio XYZ harus fokus pada peningkatan atribut layanan penyiaran terutama pada faktor fisik, keandalan, ketersediaan jaringan, layanan pelanggan secara keseluruhan. Hasilnya juga menunjukkan bahwa kombinasi atribut layanan memiliki pengaruh kuat pada kepuasan. Temuan ini menunjukkan bahwa ada hubungan positif yang signifikan antara kombinasi layanan yang dimodifikasi dengan dimensi SERVQUAL dan kepuasan pelanggan. Ini berarti bahwa dimensi kualitas layanan secara keseluruhan memiliki dampak signifikan pada kepuasan pelanggan.

Penelitian ini terbatas pada ukuran sampel yang relative terbatas sehingga generalisasi tidak dapat dilakukan. Penelitian berikutnya disarankan untuk menambah ukuran sampel dan menggunakan faktor biografis seperti jenis kelamin, pekerjaan, dan usia sebagai pemoderator hubungan kualitas dengan kepuasan konsumen.

\section{REFERENSI}

Ahmed, I., Nawaz, M., Usman, A., Shaukat, Z., Ahmad, N. and Iqbal, H. (2010). Impact of Service Quality on Customers Satisfaction: Empirical evidence from telecom sector of Pakistan. Interdisciplinary Journal of Contemporary Research in Business,1(12), 98-113

Gilski, P., \& Stefański, J. (2016). Digital audio broadcasting or webcasting: a network quality perspective. Journal of Telecommunications and Information Technology, (1), 9-15.

Gronroos, C. (2001). The perceived service quality concept -a mistake? Managing Service Quality. 11 (3), 150-152

Henkel, D. Houchaime, N. Locatelli, N. Singh, S. Zeithaml, V.A. and Bittner (2006). The Impact of Emerging WLANs on Incumbent Cellular Service Providers in the U.S. M.J. Services marketing, McGraw-Hill Singapore

Kotler, P. \& Keller,L.K. (2006). Marketing management (12thed). Pearson Education, Inc.,Upper Saddle River, New Jersey.

Larsen, H. (2016). The Crisis of Public Service Broadcasting Reconsidered. In Performing Legitimacy (pp. 79-99). Palgrave Macmillan, Cham.

Noudoostbeni, A., Kaur, K., \& Jenatabadi, H. (2018). A Comparison of Structural Equation Modeling Approaches with DeLone \& McLean's Model: A Case Study of Radio-Frequency Identification User Satisfaction in Malaysian University Libraries. Sustainability, 10(7), 2532. 
Parasuraman, A., Zeithaml, V., \& Berry, L.L. (1985). A conceptual model of service quality and its implications for future research. Journal of Marketing, 49, 41-50.

Parasuraman, A., Zeithaml, V. A. \& Berry, L. L. (1988). SERVQUAL: A Multi Item Scale For Measuring Consumer Perception of Service Quality. Journal of Retailing, 64, 12-40

Parasuraman, A., Zeithaml, V. and Berry, L.L. (1991). Refinement and reassessment of the SERVQUAL scale. Journal of Retailing, 67 (4), 420-50

Potluri, R. M. and Mangnale V. S (2010). An Assessment of Ethiopian Telecom CustomerSatisfaction. Global Journal of Management and Business Research, 10(4) 10-15

Suryani,\& Hendryadi. (2015). Metode Riset Kuantitatif Teori dan Aplikasi Pada Penelitian Bidang Manajemen dan Ekonomi Islam.Jakarta: Prenadamedia Group

Tilahun, M. (2016). Assessment Of Factors Affecting Customer Satisfaction On The Mobile Service Of Ethio Telecom (Doctoral dissertation, St. Mary's University).

\section{PROFIL PENULIS}

Ermalina adalah dosen di Program Studi Manajemen, STIE Ahmad Dahlan, Jakarta. 